\title{
Ekphrasis and the Holocaust: Traumatic Images in Jonathan Littell's The Kindly Ones
}

\section{Introduction}

On its publication, a German reviewer of Jonathan Littell's The Kindly Ones (2006; 2009 in English) referred to the author as a "pornographer of violence" (Burke 2009). By now, the novel has become one of the most notorious examples of Holocaust perpetrator fiction: 975 pages of Nazi perpetration as depicted from the viewpoint of an SS Nazi officer, Max Aue, who helps to implement and carry out the Nazi Judeocide. On first publication, Littell's work was met with immediate critical acclaim - the novel won, for instance, both the Grand Prix du Roman de l'Académie française and the Prix Goncourt in 2006, was translated into a number of languages, and made international bestseller lists - but it was also met with hostility. David Gates, in the New York Times, for instance, claimed that the novel and its author "dance on the edge of impertinence" (Gates 2009). The main point of contention for most readers, as well as critics, is its explicitness: its excessive descriptions of bodily functions; its reveling in detailed and problematic depictions of sex; but, in particular, its graphic representations of violence that are, despite the subject matter, not commonly found in Holocaust writing. Littell's diligently researched, sweeping narrative firmly focuses on the brutal crimes committed by the Nazis by depicting them - in great detail - from the point of view of the actual perpetrator. Yet it also intersperses this narrative with different viewpoints in order to, as Erin McGlothlin points out, "provide alternative perspectives on the events" and to offer "an ethical counterweight to the perpetrators' myopic views of them" (McGlothlin 2016: 253). This chapter will, as its starting point, focus on the accusation leveled at Littell for being a "pornographer of violence" by differentiating pornography from the narratological device of ekphrasis.

In its basic understanding, the term pornography refers to "books, magazines, films, etc. with no artistic value that describe or show sexual acts or naked people in a way that is intended to be sexually exciting." ${ }^{1}$ Without wishing to embark on a defense of pornography, it has to be stated that the definition of

1 https://dictionary.cambridge.org/dictionary/english/pornography

Ә OpenAccess. (c) 2020 Christine Berberich, published by De Gruyter. (cc))BY-NC-ND This work is licensed under the Creative Commons Attribution-NonCommercial-NoDerivatives 4.0 License. 
this cultural form having "no artistic value" is simply too limiting. In recent years, the term pornography or porn has been applied more liberally in other areas: "food porn," for instance, an informal expression referring to "images that portray food in a very appetizing or aesthetically appealing way." Here, the shift has been made from the original meaning of porn as having "no artistic value" to something that has become "aesthetically appealing." In both cases, though, "porn" is something that involves and even invites a look, a glance a potentially furtive and secretive one in the first case, a more directed one in the second. It seems to be produced to compel the audience to look, for a variety of reasons. Cue, then, the expression "pornography of violence," which seems to suggest, taking into account both definitions above, a cultural production that is either without aesthetic merit or that is produced in an aesthetically pleasing way, despite its subject matter. "Pornography of violence," potentially, could be accused of merely trying to aestheticize violence. In an article on the pornography of violence from 2014, the novelist Will Self recounts his personal experiences having written a piece that imaginatively recreates the last moments in the life of a hostage held by the Islamic State movement before the individual's execution. In the article, Self ponders our willingness to watch and engage with horror on an almost daily basis without, however, meaningfully engaging with it - and I will come back to this further on in this chapter. Violence, in some cases, is presented in an entirely unmediated form - as just that, the uncommented depiction of violence - and, in others, in an aestheticized form that aims to frame it as a work of art. This is where both pornography of violence and the aestheticization of violence differ from the ancient concept of ekphrasis.

\section{The meaning(s) of ekphrasis}

Ekphrasis, according to John Heffernan, is "the verbal representation of visual representation" (1993: 3). This can be a textual or spoken description of, say, a painting, a photograph or a scene in a film. In fact, for most contemporary critics, ekphrasis is the verbal depiction of a piece of art. Giddon Ticotsky, for instance, asserts that "ekphrasis is the practice whereby one work of art, mostly literary, is inspired by and significantly refers to another concrete, musical, or plastic artwork, such as a sonata, painting, statue, or building (in Greek, ek means 'fully' and phrasis means 'explicate')" (Ticotsky 2014: 7). This definition of ekphrasis might make its inclusion in a study of a Holocaust text questionable:

2 https://www.google.com/search?q=Dictionary\#dobs=food\%20porn 
as a rule, Holocaust texts do not focus on descriptions of art, music, or sculpture. But, and as Ticotsky explains, "the original meaning of the term is 'accurate description"” (2014: 7). This reference to the "original meaning of the term" is of particular importance for this chapter. As Ruth Webb, one of the leading scholars on ekphrasis, has shown, contemporary definitions of the term have become quite fluid and largely ignore its ancient meaning and usage. She explains that "as far as the [ancient] rhetoricians were concerned, ekphrasis could be a description of a person, a place, even a battle, as well as of a painting or sculpture" (Webb 1999: 8, emphasis mine). From the nineteenth century onwards, as she shows, it is this latter meaning of ekphrasis as a representation of a painting or a sculpture that has taken over and been given more prominence, in particular by thinkers such as Roland Barthes who, in "L'effet du reel," focuses mainly on "des oeuvres d'art," ignoring the ancient category of events altogether (Barthes, as quoted in Webb 1999: 12). Webb, in contrast, highlights in particular ekphrasis's ancient focus on battles, which, she explained, would traditionally "progress from an account of what preceded the battle to the event itself, and then to its aftermath" (Webb 1999: 12). This suggests that, in its original usage, ekphrasis would manifest itself in lengthy verbal descriptions of battle preparations, the actual fighting, and its often very gory aftermath, which would have been a true gift to the rhetoricians of the day.

In this sense, it is important that ekphrasis fills a void: it describes something that might not actually be present at the time, and thus makes it accessible to more people than the original visual representation had been. Ekphrasis tries to relate between different artistic media - not just by describing something, but also by investing what is described with feelings and emotions, with an interpretation. A battle scene, in ekphrastic terms, would thus not merely be the literal description of the fighting, but take in and assess the feelings and emotions, potentially even the pain of the parties involved. Consequently, it often triggers affective (i.e., very personal and sensory) responses in the reader or listener. It is, then, this ancient use of ekphrasis in particular that this chapter will focus on. The Kindly Ones, as will be argued, focuses in great detail - and with much attention to graphic detail - on events from the Holocaust, including mass shootings and massacres. Traditional Holocaust writing generally shies away from being overly descriptive, instead often focusing on matter-of-fact listing of events and procedures. In the process, an iconography of Holocaust writing has developed, an almost unspoken code of conduct, of "dos" and "don'ts" that should be adhered to for an ethically and morally correct representation of the Holocaust that is respectful to the victims. More recent Holocaust writing, however, has become more experimental, with some stylistic shifts towards more descriptive narratives that seemingly push the boundaries of Holocaust narrative. This chapter 
thus contends that these graphic depictions of violence in The Kindly Ones should be read as an ekphrastic narrative strategy that aims to paint pictures of actual and very distressing historical events for the reader in order to force a far more in-depth engagement with the violence perpetrated during the Holocaust. They are not an aestheticization of violence; nor are they pornography of violence. They are provided to critically engage the reader and make him or her think about why they want to read such graphic violence in the first place.

\section{The Holocaust and cultural representation}

Since 1945, Holocaust representation has gone through a number of stages. Bernhard Giesen has termed these different "institutional arenas," highlighting that Holocaust representation has moved from the initially public (through the first few trials) to the private (through the conspiracy of silence that denied opportunities for public engagement) to the more specialized arenas of academic and expert engagement to, finally, a wide-ranging public arena addressed through monuments, museums, and, increasingly, cultural output such as film, TV productions, and, in particular, literature (Giesen 2004: 141).

For Giesen, cultural representations of the Holocaust have "transferred the issue [of commemoration] to a new institutional arena that tends to overcome opposition and conflicts by the ritual construction of communality" (Giesen 2004: 141). Films, he argues, "present a story and not an argument" - which means that nobody in the audience would argue with the fundamental content and evaluation of the Holocaust (Giesen 2004: 141). There is, however, fierce resistance to cultural representations of the Holocaust in film and literature, with critics such as Berel Lang in particular focusing on the very fact that they "present a story." They argue that only facts can speak for the events of the Shoah and that literature cannot and should not attempt to represent it (see, for instance, Lang 1995: 84-89). Despite their resistance, though, writing about the Holocaust widely has, potentially, had the same effect as the one that Giesen commented on in the context of film. Survivor memoirs have contributed enormously towards shedding more light on the plight of the victims of the Holocaust. In the course of this, though - and this is by no means a criticism of such memoirs - they have contributed towards an iconography in representations of the Holocaust that is, for obvious reasons, victim-focused and that has, by extension, allowed for readers' and viewers' ready but problematic identification with the victims. Identifying with the victims inevitably results in an affective and empathetic response that does not allow for a critical engagement with "the other side," with the causes that led multitudes of Germans to willingly 
participate in mass atrocities and genocide. Critics such as Gillian Rose (1996) have, in a provocative response to this, called for "Holocaust impiety": for different forms of Holocaust representation, be it in film or literature, that problematizes and challenges the overly simplified "good" vs "bad," "victim" vs "perpetrator" dichotomy. Literature, and here, in particular, Holocaust fiction, lends itself to do just that: to approach the Holocaust from a variety of angles. This does not mean, as critics of Holocaust fiction have alleged, that "to write Holocaust fiction is tantamount to making a fiction of the Holocaust" (Vice 2000: 1). Rather the opposite. Of course, fictional representations of the Holocaust also "present a story," but they aim to present different "stories," different approaches and perspectives to the Holocaust. Recent years have seen an increase in perpetrator narratives - a term that, in my interpretation, encompasses fiction of actual Holocaust perpetration but also narratives about the "ordinary German bystanders." Prominent recent examples in the latter category are Rachel Seiffert's The Dark Room of 2001 and Audrey Magee's The Undertaking of 2014, as well as the both highly acclaimed and critiqued German mini-series Generation War / Our Mothers, Our Fathers of 2013. Novels about actual real-life perpetrators of atrocities against the Jews are probably a lot more contentious and consequently still scarce. Prominent examples here would be David Albahari's Götz and Meyer of 2004 or Hubert Mingarelli's evocative A Meal in Winter of 2012. These narratives depart considerably from the more traditional, victim-focused narrative by offering up accounts about those complicit in the crimes of the Holocaust. They do so not in the spirit of offering exculpation of the perpetrators, but to provide different perspectives. McGlothlin has convincingly argued that "such texts emphasize the humanness of their Nazi protagonists and in doing so complicate the reified image of Holocaust perpetrators that has developed in the decades since the war” (McGlothlin 2016: 253). These narratives can have a destabilizing effect on their readers, conditioned by decades of representations showing Nazis as over-simplified and caricatured Pantomime villains (Rau 2013). Perpetrator texts, in contrast, urge readers to assess both their own motivation in reading Holocaust accounts, and their moral universe. In Rose's words, Holocaust perpetrator accounts leave readers "unsafe," forcing them to look at the events of the Holocaust through different eyes (Rose 1996: 48).

These texts have an additional value: they address the Holocaust head on and do not offer their readers a chance to hide behind generalities. The Israeli political sociologist Ronit Lentin, who has written at length about the fact that the Holocaust tests conventional representational categories, has explained that, for most people, the Holocaust has become a "euphemism, a metaphor, a code," "standing for something that one does not want to hear mentioned" (Lentin 2004: 5-6). This means that, while most people have a basic knowledge 
of the Holocaust, it is not something that they want to deal with at close range. Matthew Boswell has similarly argued that people are "broadly unwilling to face the horrific content of what happened" - we might know the basic facts, but we do not want to look at them in more detail, and certainly not in a way that asks uncomfortable questions of ourselves (Boswell 2012: 32). And this is where the use of ekphrasis can be such a valuable tool in Holocaust studies: by conjuring up images of the Holocaust - painful, brutal, uncomfortable - it forces the reader to look, to address the very thing rather than just think about it as a euphemism or as an abstraction. For Pablo Gonçalo, the importance of ekphrasis lies in the "aesthetic and sensory effects triggered by [...] shifts between languages, media and different materialities” (Gonçalo 2017: 85). Detailed verbal descriptions of gruesome events or atrocities stop us from looking away; they direct our gaze and force us to engage with what is being described for us. As Webb has explained, ancient rhetoricians "define[d] ekphrasis first and foremost as a type of speech (logos) that has a certain effect upon an audience. An ekphrasis appeals to the mind's eye of the listener, making him or her 'see' the subject-matter" (Webb 1999: 11-12). Through ekphrasis, the reader effectively becomes a spectator (Gonçalo 2017: 85) - and, by extension, a participant. The result is that formerly clear-cut identifications are challenged, and, often, the reader has to confront the uncomfortable question, "What would I have done?"

\section{Traumatic images in The Kindly Ones}

Littell uses ekphrasis in his extremely graphic depictions of violence, leaving the reader with terrorizing images that remain long after the novel has been finished. These cover diverse events of the war, such as the traumatic siege of Stalingrad, the execution of civilians and resistance fighters, and mountains and mountains of corpses. But Littell also turns the focus of ekphrastic description on his protagonist Max Aue: readers are constantly confronted with detailed imagery surrounding Aue's bodily malfunctions - descriptions of vomit and shit abound as well as his sexual preferences, which include anally raping his twin sister on a guillotine or impaling himself on a tree branch while out for a walk. The most prominent and detailed example of ekphrasis comes early in the novel, where ten pages of Aue's narrative are dedicated to a graphic depiction of the massacre at Babi Yar. Between 29 and 30 September 1941, 33,771 Ukrainian Jews were systematically murdered by the Nazis just outside the city of Kiev, with many more Jews, as well as Roma and Russian prisoners of war, murdered 
over the following months; estimations now run up to 100,000 victims in total. ${ }^{3}$ Babi Yar has become notorious as one of the largest massacres of the Second World War, and, as such, it has been commemorated in a variety of ways: in 1947, the Soviet writer Ilya Ehrenburg published the novel Burya (The Storm) which describes the massacre, but his efforts, along with those of fellow Soviet writers and artists who called for a memorial at Babi Yar, were brushed aside in the Soviet anti-Semitic purges of the late 1940s. ${ }^{4}$ In 1961, Yevgeny Yevtushenku wrote his celebrated poem "Babi Yar," whose oft-quoted line "No monument stands over Babi Yar," immortalized in Shostakovich's $13^{\text {th }}$ Symphony from 1962, challenged the lack of official Soviet commemoration (Kinstler 2016). ${ }^{5}$ D. M. Thomas's The White Hotel from 1981 contains an account of Babi Yar that leans heavily on the eyewitness account of Dina Pronicheva from $1946 .{ }^{6}$ While there are, in fact, a number of cultural commemorations of Babi Yar, the massacre is nevertheless not commonly known, nor widely taught - and, in fact, there still is no dedicated monument to mark the site. This is what makes Littell's engagement with Babi Yar so remarkable. In The Kindly Ones, the reader is taken, step-by-step, through the build-up to the massacre, following "the flow of Jews" as they line up and slowly walk to the ravine that will become their mass grave (Littell 2009: 123). Littell here plays heavily with imagery to describe the gathering Jews as a "stream of people," as "human streams," "pouring out of all the side streets," and as "streams merging into the river" (Littell 2009: 123). This repeated stream metaphor is an ekphrastic device that helps to draw a picture for the reader: the sheer numbers of Jews assembling, gathering momentum, moving inexorably towards their own destruction, is depicted as an increasing swell of water that rushes unstoppably towards a precipice. However, it also helps to depersonalize the soon-to-be victims. Rather than looking at them as individuals, they are being depicted as a faceless mass. This detached attitude is further emphasized by Aue's focus on the almost clinical procedures he witnesses - "the Jews had to hand over their papers, then their money, their valuables and jewelry, then the keys to their apartments, legibly labelled, and finally their clothes and shoes" (Littell 2009: 124). In the process, the Jews are not only stripped of their possessions but also their individuality. With descriptions such as these, Littell follows the well-trodden part of historical narratives and films, outlining procedures that have become well-known and documented parts of

3 Information taken from the United States Holocaust Memorial Museum webpage.

4 See http://www.jewishvirtuallibrary.org/babi-yar.

5 See also http://www.jewishvirtuallibrary.org/babi-yar.

6 See http://www.yadvashem.org/yv/en/education/learning_environments/babi_yar/written_ testimonies.asp. 
the Nazis' machinery of mass destruction. But this is juxtaposed with more evocative imagery - and this time, imagery that literally uses photographs as its starting point. Outside the ravine checkpoint, Aue finds "torn passports, workbooks, union or ration cards, family photos" that lead him to reflect on the "happiness and normality of their lives before all this" (Littell 2009: 125). The "snapshots, studio portraits, of men, women, and children, grandparents and chubbyfaced babies; sometimes a shot of vacation scenery" makes him recall his own troubled childhood and his fervent wish for "normality" then (Littell 2009: 125). The photographs remind Aue of the humanity of the very "stream of people" he had tried to strip of their individuality earlier. It is probably unsurprising that his mind wanders. Instead of forcing himself to look at the humans in front of him, he retreats into childhood memories and a traumatic event in his own past. His personal trauma thus effectively overwrites the current traumatic events he experiences and becomes a problematic escape mechanism that stops him from understanding or even engaging with the trauma that he and his fellow soldiers inflict upon the Jews of Kiev.

The focus shifts again: as soon as Aue enters the ravine, the almost industrialized violence that is being perpetrated here stands in the foreground:

[T] he ravine stretched out in front of me [...]. Boards had been placed over [the] stream so the Jews and their shooters could cross easily; beyond, scattered pretty much everywhere on the bare sides of the ravine, the little white clusters were multiplying. The Ukrainian "packers" dragged their charges to these piles and forced them to lie down over them or next to them; the men from the firing squad then advanced and passed along the rows of people lying down almost naked, shooting each one with a submachine bullet in the neck. (Littell 2009: 126)

Aue paints a quasi-cinematic picture of what took place in the ravine: it provides a distanced description, almost from above, and certainly disembodied, of what went on. Aue's tone is detached and impersonal. At this point, although the descriptions are distressing, they are still within the realm of traditional, realist, and matter-of-fact historical accounts. As in the traditional definitions of ekphrasis, Aue here details what could be seen as the run-up to the actual "battle," the moment when Aue himself will inevitably have to take an active part in the shootings. Yet the detached tone changes as soon as Aue himself starts to take part in the executions and his language reflects his personal experiences: "A very young man was sobbing in pain, I aimed my gun at his head and squeezed the trigger, but it didn't go off, I had forgotten to lift the safety catch, I lifted it and shot him in the forehead, he twitched and was suddenly still" (Littell 2009: 128). The punctuation in this sentence is telling - commas instead of full stops do not allow either the narrator nor the reader to "pause" and contem- 
plate what they are seeing/doing/reading; the merging of the very emotive "sobbing in pain" - with the pragmatic - "I had forgotten to lift the safety catch" - shows the narrator's attempt not to focus on the human aspect of what surrounds him but to turn himself into a machine. He focuses on his task - "to finish off the wounded" (Littell 2009: 128) - even though "to reach some of the wounded, you had to walk over bodies, it was terribly slippery, the limp white flesh rolled under my boots, bones snapped treacherously and made me stumble, I sank up to my ankles in mud and blood" (Littell 2009: 128). Again, there are commas instead of full stops to prevent the narrator from pausing to take stock. The traumatic experience fills Aue with self-confessed "disgust" (Littell 2009: 129) - he refuses to assess the situation he finds himself in and, instead, escapes to a traumatic childhood memory that saw himself assaulted by masses of swarming cockroaches in a small, enclosed space. Aue's narrative becomes increasingly hysterical, reflecting the chaos of the massacre, firing "almost haphazardly at anything I saw wriggling," with other soldiers and officers around him "shaking and drinking between batches," "laughing insanely and emptying [their] cartridge clip at random” (Littell 2009: 129). This scene perfectly encapsulates what Webb outlines as the ancient usage of ekphrasis as a "form of vivid evocation" (Webb 1999: 13). Webb relates this to the ancient form of energeia, which she sees "at the heart of ekphrasis": an energetic, vivid narrative that results in "a mental impression in the mind of [the] audience” (Webb 1999: 13). Aue's unpunctuated narrative sweeps the reader along; his unmediated trauma at what he takes part in is passed on to the reader. “A successful orator," Webb explains, "must move his audience, must make them feel as if they were present at the events described" (Webb 1999: 13). Littell's ekphrastic narrative strategies succeed in making his reader walk alongside Aue at Babi Yar, and this is particularly prominent in a final example from this section:

[M]y gaze met that of a beautiful young woman, almost naked but very elegant, calm, her eyes full of an immense sadness. I moved away. When I came back she was still alive, half turned onto her back, a bullet had come out beneath her breast and she was gasping, petrified, her pretty lips trembled and she seemed to want to form a word, she stared at me with her large surprised incredulous eyes, the eyes of a wounded bird, and that look stuck into me, split open my stomach and let a flood of sawdust pour out, I was a rag doll and didn't feel anything, and at the same time I wanted with all my heart to bend over and brush the dirt and sweat off her forehead, caress her cheek and tell her that it was going to be all right, that everything would be fine, but instead I convulsively shot a bullet into her head, which after all came down to the same thing, for her in any case if not for me, since at the thought of this senseless human waste I was filled with an immense, boundless rage, I kept shooting at her and her head exploded like a fruit, then my arm detached itself from me and went off all by itself down the ravine, shooting left 
and right, I ran after it, waving at it to wait with my other arm, but it didn't want to, it mocked me and shot at the wounded all by itself, without me. (Littell 2009: 129-30)

This paragraph, with its problematic juxtaposition of the empathetic - the beautiful young woman, her terror and pain - and the distanced - Aue's focus on his own bodily response to disengage himself from the horror he is committing - is deeply affective; it has the exact opposite effect on the reader than it has on Aue. While Aue is trying to distance himself - the fact, for instance, that he describes her head as a mere piece of fruit - this is impossible for the reader. The ekphrastic, vivid description of the scene involves the reader too much. At a personal level, this is the section of the book where my own affective response to the text began to dominate and I stopped reading during my first attempt to get through The Kindly Ones. Firmly entrenched on my own ethical and moral high horse, I could not deal with the graphic depictions of blood, guts, and violence in Aue's narrative that seemed unnecessarily detailed. Like the German reviewer, I too, felt that it was almost pornographic in its seeming reveling in violence. Although I had read countless examples of Holocaust memoirs and fiction prior to reading The Kindly Ones, I had not been confronted with the same level of sheer violence. Although all of the other texts had engendered a deeply emotive response in me, most were restrained in their depictions of violence, using more factual language, moving on swiftly instead of lingering on blood and violence, or else leaving gaps for the reader to fill in imaginatively. Littell uses no such gaps - he forces his readers to, literally, look and take in everything: the violence, the smell, the hysteria. But, as readers, we do not simply consume this horror - we engage with it; we recoil from it. And it is these processes that make us think.

In the shooting scene of the beautiful young woman, we are not confronted with a "faceless" victim; we get a detailed description - of her looks, of her pain, and of Aue's response to the atrocity he commits. The Guardian's Jason Burke celebrates Littell's use of "narrative photo realism" (Burke 2009: n.p.) that uses text instead of actual images. This "photo realism" perfectly encapsulates ekphrasis in its ancient usage: Littell describes, in painstaking detail, scenes of actual historical atrocity, thus painting a picture for the reader which, in turn, affects the reader and engenders a deeply emotive response. Importantly, Littell also fills a void with these descriptions: after completing the massacre, the Nazis dynamited the site of the ravine to cover up the bodies - but then came back months later to exhume the corpses and incinerate them in mass pits on site. The site of Babi Yar is now a recreational area easily accessible by tram from Kiev. There are no visible markers of the atrocities, no monuments, no memorials, no plaques commemorating the names of the dead (Kinstler 
2016). Littell's narrative strategy enables his readers to, in Gonçalo's definition of ekphrasis, “visualize scenes, places, occasions and historical events” (Gonçalo 2017: 85). In the midst of bloodshed and carnage, Littell brings Babi Yar back to life and, in effect, creates a monument to its victims.

\section{Aestheticizing violence, or readerly engagement?}

Despite this, Littell's overtly graphic violence is troubling. As readers, we are encouraged to walk in Aue's, and, consequently, the perpetrator's, shoes, accompanying him on his killing sprees in what, naturally, makes for very uncomfortable reading. When Aue pulls the trigger, we are right by his side; when he describes the scenes of mass murder, we "see" them with him. Through these ekphrastic images, Littell renews the debate on the "Grey Zone" that Holocaust perpetrator fiction inhabits: it challenges questions of ethics of representations, of what is, and what is not, ethical to depict in Holocaust fiction. This is exacerbated by Aue's repeated assertions to the reader that he is "a man like other men," "a man like you," that he is, in fact, "just like" us (Littell 2009: 24). Many critics have focused on Littell's narrative strategy of presenting Aue as an "everyman," and on his constant interactions with the reader. ${ }^{7}$ But it is, in particular, the many appeals to the reader, alongside his affecting depiction of violence, that makes Littell's text so remarkable, and there are a number of possible readings of this.

Reading one might simply be that Littell aims to aestheticize violence in a similar way to other postmodern and experimental novels, such as Ballard's Crash or Ellis's American Psycho. Critics have commented on Littell's liberal use of graphic violence, and in many instances have seen this as the novel's shortcoming compared to its historical accuracy and painstaking research. For example, Roman Leick, a reviewer for the German news magazine Der Spiegel, asks whether Littell's use of graphic violence, often with a sexual undertone, provides “added literary merit? Or [mere] pornographic voyeurism?” (Leick, as quoted in Kuon 2012: 34). For Peter Kuon, it seems to suggest that Littell is caught "between two poles - a commitment to historical precision and the desire for artistic creation" and that he "opts for aesthetics over documentation" (Kuon 2012: 34). This "aesthetics" can take the form and shape of a late twentieth-century splatter movie - the earlier quoted passage, of soldiers "laughing insanely and

7 See, for instance, Hutton 2010: 1-15; Michaels 2013: 915-930; or Meretoja 2016: 371-404. 
emptying [their] cartridge clip at random," could be taken straight out of a Tarantino film. As Kuon says, "aesthetics and ethics are in conflict” (Kuon 2012: 42): Littell makes aesthetic decisions - to stage and literally depict violence in a certain way in order to enhance his narrative - that tap into contemporary society's fascination with violence and spectacle. Some critics argue that these decisions could ultimately impact the ethical representation in a Holocaust-based narrative, and thus open up the novel to severe criticism from readers and scholars alike who, in many cases, decry the very fact that the Holocaust is presented in fictional narratives at all. Alternatively, though, Littell's graphic descriptions might get the reader to ask uncomfortable questions about their own readiness to confront traumatic images. Will Self, in his article on the Islamic State executions referred to earlier, states:

We witnessed the emaciated corpses piled up like broken manikins beside the train tracks that led to Sobibór, Treblinka and Auschwitz-Birkenau; we saw the Vietnamese girl running along the muddy road, naked save for a cloak of napalm; we goggled at the poor souls who flung themselves from the smoking flanks of the twin towers - we've endured an entire lifetime of silence and passivity in the screaming face of annihilation, so naturally we're well prepared to watch a video of a man having his head cut off. (Self 2014: n.p.)

This quote suggests that, as readers and viewers, we have become so accustomed to seeing horror that we do not flinch anymore, that we can distance ourselves and detach from the narrative depicted or described to us. Littell tackles this preconception head-on by confronting us with horror about a topic that has, traditionally, always been approached cautiously.

A second potential reading might explain the focus on violence as an attempt to gain readerly empathy for the protagonist Aue. In her book Séductions du bourreau, negation des victims, which predominantly focuses on Littell's The Kindly Ones, the French critic Charlotte Lacoste argues that books such as Littell's form part of a perverse new fashion in that they focus on a dangerous equation: if perpetrators are ordinary, as we all are, then we are all, effectively, perpetrators (Lacoste 2010). Lacoste's work looks at the empathy Littell's work could create, which, potentially, would force us to identify with the perpetrators and even exonerate them, a reading which certainly highlights the inherent dangers in over-empathizing with fictional characters. The opening section of The Kindly Ones serves as a starting point for this kind of reading: throughout the first 24 pages of the narrative, Aue constantly addresses the reader with uncomfortable questions - "So who is guilty? Everyone, or no one?" - culminating in his provocative statement "but don't think I'm a devil. [...] Those who kill are humans, just like those who are killed, that's what's terrible” (Littell 2009: 19; 24). While this section of the book certainly aims at creating a complicity with the 
reader, I would argue that Lacoste's reading is too reductive. It is a provocative opening, certainly; I would also agree that Littell's novel plays with the notion of reader empathy. But I would contend - and I will expand on this below - that this empathy is not necessarily aimed solely at getting the reader to identify with Aue or to exonerate his crimes.

Rather, and this is the third potential reading of the novel, empathy is used to make the reader question their own motives in reading the novel in the first place.

In this final reading, the reader asks him or herself a number of troubling questions: Why am I reading this? And, importantly: What would I have done? McGlothlin has stated that texts such as The Kindly Ones allow "us to investigate the ways in which texts construct and compel readers' empathic and identificatory responses to their protagonists" but simultaneously warns against oversimplifying this (McGlothlin 2016: 254). Most readers, she has argued, seem to believe that empathy always and inevitably has to be positive, resembling compassion for a character - and this would, of course, be highly problematic when applied to readings of Holocaust perpetrators. As Suzanne Keen has pointed out in Empathy and the Novel, "the opportunity to think and feel with those from whom we would ordinarily recoil in horror provides one of the much-touted advantages of fictional world-making" (Keen 2007: 131). Novels foregrounding perpetrators and the violence they committed during the Holocaust thus allow their readers different perspectives and insights. For McGlothlin, the crux of The Kindly Ones is "not that such narratives elicit our sympathy in order that we forgive the perpetrators' participation in genocide, but that they ask us to align in various and often uncomfortable ways with their perspective even as we become aware of their violent actions" - and this is certainly a view I would concur with (McGlothlin 2016: 258). For many readers, the violent scenes in The Kindly Ones are a deterrent, or something that makes them stop reading halfway through, as I myself did on my first reading. The violence in the novel has the potential to morally enrage, as it does not fit into our preconceptions of what Holocaust writing should and shouldn't do. But that in itself is reductive, too. Of course the use of violence is disturbing and repellent, but it is never an attempt to raise empathy for or understand the perpetrator. Rather, in the words of Emily Miller Budick, "The Kindly Ones [...] holds up a dark, distorted, and yet frightening revealing mirror to the field of Holocaust studies itself, which has everything to do with our sometimes prurient interest in other people's suffering and with how we do and do not see ourselves reflected in narratives of the Holocaust" (Budick 2015: 15). The traumatic images in The Kindly Ones are important because they force the reader to confront the reality of the 
Holocaust instead of dealing with it in an abstract way to protect our own sensibilities.

\section{The impact of ekphrasis}

Littell's The Kindly Ones then indeed "complicate[s] the reified image of Holocaust perpetrators that has developed in the decades since the war" (McGlothlin 2016: 253). It complicates the whole concept of Holocaust representations through its explicit use of graphic violence that appears to break various and probably largely unspoken codes of ethical narrative representations of the Holocaust. Aue, as Margaret-Anne Hutton has commented, "is an actor in the Holocaust, but he is also a spectator of both others and of himself" (Hutton 2010: 6). But this assessment can be extended to the reader. As Webb has outlined, ekphrasis is characterized by the "psychological impact of the word and the imaginative contribution of the listener" (Webb 1999: 18). Aue describes the events of the Holocaust that he himself participates in; he paints a picture for the reader that, of course, includes him. By extension, though, the reader becomes spectator - by reading the novel, by looking at the traumatic images Aue paints for us - and actor - by engaging with the horrors of the Shoah through the very process of actively engaging with the images Aue describes. So, in response to the three potential readings of the novel offered earlier - the anesthetization of violence, the aiming at readerly empathy that could also be a negative empathy, or the focus on readerly engagement with and responses to the novel I would suggest that there is a combination of all three. In using an ekphrastic narrative to vividly describe violent scenes and by offering us "mental images" and "word[s] as dynamic force" (Webb 1999: 18), Littell certainly does frame his violence aesthetically and with artistic embellishments; he certainly tries to put the reader in a position where he or she has to engage with the perpetrator's actions in an uncomfortably close manner. Most importantly, though, he addresses us, the readers, directly and questions our very reading of his novel in the first place. As Jason Burke pointed out in The Guardian, Littell's "opening sentence - ' $\mathrm{O}$ my human brothers, let me tell you how it happened' - recalls, especially in the French original, Charles Baudelaire's: 'Hypocrite lecteur, mon semblable, mon frère”" (Burke 2009: n.p.). Tell me, hypocrite reader, my mirror image, my brother - why are you reading my book? 


\section{Works cited}

Alexander, Jeffrey C. (2004) "On the Social Construction of Moral Universals: The 'Holocaust' from War Crime to Trauma Drama," in Jeffrey C. Alexander, Ron Eyerman, Bernhard Giesen, Neil J. Smelser, and Piotr Sztompka (eds.), Cultural Trauma and Collective Identity (Berkeley: University of California Press), pp. 196-262

Bos, Pascale R. (2005) German-Jewish Literature in the Wake of the Holocaust: Grete Weil, Ruth Klüger, and the Politics of Address (New York: Palgrave Macmillan)

Boswell, Matthew (2012) Holocaust Impiety in Literature, Popular Music and Film (London: Palgrave Macmillan)

Budick, Emily Miller (2015) The Subject of Holocaust Fiction (Bloomington: Indiana University Press)

Burke, Jason (2009) “The Evil Ordinary Men Can Do," The Guardian (22 February 2009) <https://www.theguardian.com/books/2009/feb/22/history-holocaust-books-jonathan-lit tell>. Last accessed 02/04/2019.

Fulbrook, Mary (1999) German National Identity after the Holocaust (Cambridge: Polity Press)

Gates, David (2009) “The Monster in the Mirror," New York Times (5 March 2009) <http:// www.nytimes.com/2009/03/08/books/review/Gates-t.html>

Giesen, Bernhard (2004) "The Trauma of Perpetrators: The Holocaust as the Traumatic Reference of Germany National Identity," in Jeffrey C. Alexander, Ron Eyerman, Bernhard Giesen, Neil J. Smelser, and Piotr Sztompka (eds), Cultural Trauma and Collective Identity (Berkeley: University of California Press), pp. 112-154

Gonçalo, Pablo (2017) "Film in Words / Words in Pictures: Ekphrasis Modulations in Peter Handke and Wim Wenders' Cinematic Collaborations," Journal of Screenwriting, 8.1, pp. $83-97$

Heffernan, J. A. W. (1993) Museum of Words: The Poetic of Ekphrasis from Homer to Ashbery (Chicago: University of Chicago Press)

Hutton, Margaret-Anne (2010) "Jonathan Littell's Les Bienveillantes: Ethics, Aesthetics and the Subject of Judgement," Modern \& Contemporary France, 18.1, pp. 1-15

Huyssen, Andreas (1995) Twilight Memories. Marking Time in a Culture of Amnesia (London: Routledge)

Keen, Suzanne (2007) Empathy and the Novel (Oxford: Oxford University Press)

Kinstler, Linda (2016) "No Monument Stands Over Babi Yar," The Atlantic (30 September 2016) <https:/www.theatlantic.com/international/archive/2016/09/ukraine-jewish-babiyar-russia-holocaust-germany-poroshenko/502517/>. Last accessed 02/04/2019.

Kuon, Peter (2012) “From 'Kitsch' to 'Splatter': The Aesthetics of Violence in Jonathan Littell's The Kindly Ones," in Aurélie Barjonet and Liran Razinsky (eds.), Writing the Holocaust Today. Critical Perspectives on Jonathan Littell's The Kindly Ones (Amsterdam: Editions Rodopi), pp. 33-46

Lacoste, Charlotte (2010) Séductions du bourreau, negation des victims (Paris: Presses Universitaires de France - PUF)

Lang, Berel (1995) “Is it Possible to Misrepresent the Holocaust?" History and Theory, 34.1, pp. $84-89$

Lentin, Ronit (2004) Representing the Shoah for the Twenty-First Century (New York: Berghahn Books)

Littell, Jonathan (2009) The Kindly Ones (London: Chatto \& Windus) 
McGlothlin, Erin (2016) "Empathetic Identification and the Mind of the Holocaust Perpetrator in Fiction: A Proposed Taxonomy of Response," Narrative, 24.3, pp. 251-276

Meretoja, Hanna (2016) "Fiction, History and the Possible," Orbis Litterarum, 71.5, pp. $371-404$

Michaels, Walter Benn (2013) "Forgetting Auschwitz: Jonathan Littell and the Death of a Beautiful Woman," American Literary History, 25.4, pp. 915-930

Niven, Bill (2006) "Introduction: German Victimhood at the Turn of the Millennium," in Bill Niven (ed.), Germans as Victims (Basingstoke: Palgrave Macmillan), pp. 1-25

Rau, Petra (2013) Our Nazis. Representations of Fascism in Contemporary Literature and Film (Edinburgh: Edinburgh University Press)

Rose, Gillian (1996) Mourning Becomes the Law. Philosophy and Representation (Cambridge: Cambridge University Press)

Schlant, Ernestine (1999) The Language of Silence. West German Literature and the Holocaust (New York: Routledge)

Self, Will (2014) "We are Passive Consumers of the Pornography of Violence," The Guardian (23 December 2014) <https://www.theguardian.com/news/2014/dec/23/-sp-passive-con sumers-pornography-violence>. Last accessed 02/04/2019.

Ticotsky, Giddon (2014) “Ekphrasis as Encryption: Lea Goldberg in Berlin,” Prooftexts, 34, pp. $1-52$

Vice, Sue (2000) Holocaust Fictions (London: Routledge)

Webb, Ruth (1999) "Ekphrasis Ancient and Modern: The Invention of a Genre," Word \& Image. A Journal of Verbal / Visual Enquiry, 15.1, pp. 7-18 